\title{
Density, extractives and decay resistance variabilities within branch wood from four agroforestry hardwood species
}

\author{
Florence Terrasse ${ }^{(1-2)}$, \\ Loic Brancheriau ${ }^{(1-2)}$, \\ Remy Marchal ${ }^{(3)}$, \\ Nabila Boutahar (1-2), \\ Sylvain Lotte ${ }^{(1-2)}$, \\ Daniel Guibal ${ }^{(1-2)}$, \\ Luc Pignolet ${ }^{(1-2)}$, \\ Kevin Candelier ${ }^{(1-2)}$
}

\begin{abstract}
Agroforestry practices like pruning trees to control the light flux to crops produce every year a large volume of branches which is valorized by farmers as mulching or energy fuel. However, according to the literature, the wood of branches shows higher rates of polyphenols than stem wood and this can open some new perspectives for branch exploitation. In this study, the wood properties (density, mechanical properties, extractive content and decay resistance) were determined on branches of different sizes from oak, chestnut, poplar and walnut trees collected in two agroforestry systems. These properties were evaluated according to the wood age and the sampling position along the radial and longitudinal axes of the branch. All samples were analyzed by NIR-Spectroscopy and a predicting model aimed to assess the branch wood properties has been developed. Wood characteristics largely vary between species and do not exactly follow the same trends from one species to another. Overall, hardwood density of branches is similar to that of trunks, the content in wood extractives follows similar evolutions, and the decay resistance of branch wood does not seem to be really impacted by its position along the branch. Reliable NIRS models were built to easily predict the wood density and extractives content of agroforestry branches. The extractives content and the decay resistance of branch hardwood appear to be substantially lower than those of trunks, which suggests a non-suitability of branch wood for developing highvalued green chemistry.
\end{abstract}

\section{Keywords: Agroforestry, Branches, NIR-Spectrometry, Wood Quality}

1991), biodiversity conservation (Michon \& De Foresta 1992) and above all in climate change mitigation (Hamon et al. 2009). Agroforestry trees differ from forestry trees in two ways: their roots dig deeper (Mulia \& Dupraz 2006), and they also grow faster and produce more biomass, most likely because there is less competition for the light and other resources (Dupraz \& Liagre 2008). In addition, agroforestry trees usually grow in more fertilized soils than those of forest trees. In some cases, an agroforestry tree will produce about three times more biomass than a tree of the same age in a forest (Gavaland \& Burnel 2005). This increased biomass enables agroforestry trees to potentially stock $\square$ (1) CIRAD, Research Unit BioWooEB, 34000, Montpellier (France); (2) BioWooEB, Université de Montpellier, CIRAD, Montpellier (France); (3) "Arts et Metiers" Institute of Technology, LABOMAP, HESAM University, F-71250 Cluny (France)

@ Kevin Candelier (kevin.candelier@cirad.fr)

Received: Nov 09, 2020 - Accepted: Mar 01, 2021

Citation: Terrasse F, Brancheriau L, Marchal R, Boutahar N, Lotte S, Guibal D, Pignolet L, Candelier K (2021). Density, extractives and decay resistance variabilities within branch wood from four agroforestry hardwood species. iForest 14: 212-220. - doi: 10.3832/ifor3693014 [online 2021-05-02]

Communicated by: Luigi Todaro large amounts of carbon, thereby contributing to mitigate the effects of climate change and providing a highly valuable woody resource to be used for various purposes. Since six decades, European countries (including France) have massively excluded trees from the cropfields in order to intensify mechanized agriculture. However, the current agro-ecological transition is going to reverse this trend through the design of new agroforestry systems.

Besides agricultural products, the main product specific to agroforestry systems is wood. Trunks, branches and twigs all have different potential uses due to their diverse characteristics (ADEME/Atlanbois 2016) which are summarized in Fig. S1 (Supplementary material). Throughout their life cycle, agroforestry trees mostly yield pruning wood from branches, which has the same wood orthotropic cylindrical organization as trunks (Fig. S1) and currently is mostly used as Ramial Chipped Wood (RCW) or animal litter (Malignier \& Balaguer 2017).

Branch wood has been poorly investigated compared to stem wood, and currently there is a lack of data which could support any potential added-value of the branches for any production path.

Regarding the physical aspects, some studies reported that the mechanical characteristics of branches' wood are usually reduced compared to those of the trunks 


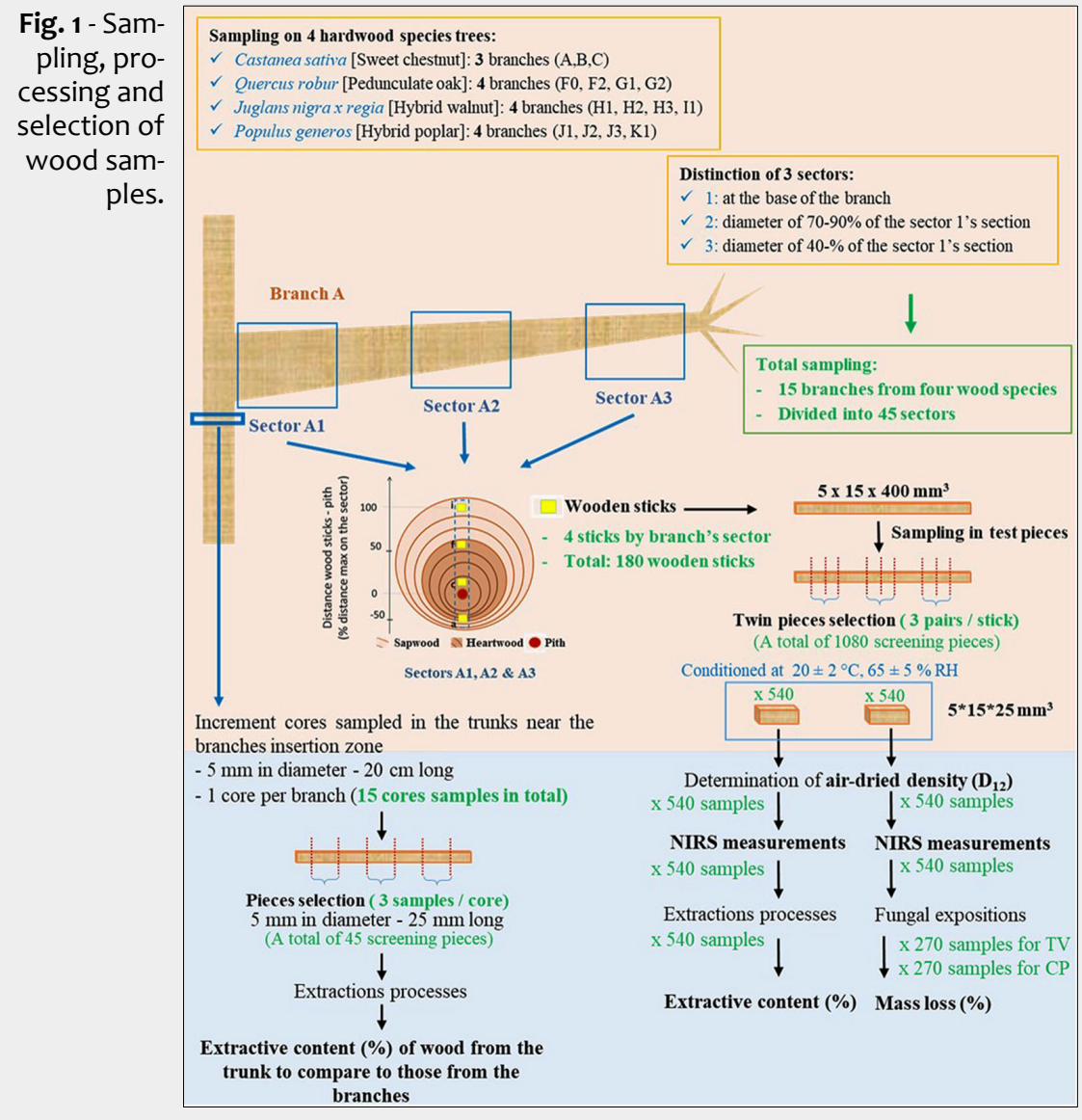

(Gurau et al. 2008). Other researchers investigated the density and anatomy of branches in several species (Dadzie et al. 2016, Kiaei et al. 2014), finding that in most cases the wood density of branches seems to be higher than that of the trunks. Yet, this characteristic, as most of other wood characteristics, seems to be highly variable depending on the tree species considered. Such differences also appear when considering wood chemical properties, which strongly change moving from one tree organ to another. Tree knots along the stem have been particularly studied, resulting in most cases richer in extractives than trunks and branches both in hardwoods and softwoods (Košíková 2009, Kebbi-Benkeder 2015). Furthermore, branches seem to be richer in extractives than the trunk clear wood, although they are poorer than the knots (Xu et al. 2007, Morikawa et al. 2014). They also present a higher durability than the trunks (Dadzie \& Amoah 2015), due to the higher content of wood extractives.

Tab. 1 - Age of the branch wood according to the position sector in the branch for the four hardwood species.

\begin{tabular}{ccccc}
\hline \multirow{2}{*}{$\begin{array}{c}\text { Branch } \\
\text { Sector }\end{array}$} & \multicolumn{4}{c}{ Age of the branch wood (years) } \\
\cline { 2 - 5 } & Chestnut & Oak & Walnut & Poplar \\
\hline Sector 1 & $9 \pm 1$ & $18 \pm 4$ & $14 \pm 2$ & $14 \pm 5$ \\
\hline Sector 2 & $8 \pm 1$ & $15 \pm 2$ & $13 \pm 1$ & $12 \pm 5$ \\
\hline Sector 3 & $6 \pm 1$ & $11 \pm 1$ & $12 \pm 1$ & $10 \pm 4$ \\
\hline
\end{tabular}

properties were then compared to those of wood from the trunk of the same trees. Additionally, all samples were analyzed by NIR-Spectroscopy with the aim of developing a fast system to assess the branch wood properties directly in the field.

\section{Material and methods}

\section{Tree selection}

The selected hardwoods species were sweet chestnut (Castanea Sativa Mill.), pedunculate oak (Quercus robur), hybrid walnut (Juglans $\times$ intermedia [C. DC.] Carrière, hybrid Juglans nigra $\times$ Juglans regia) and hybrid poplar (Populus generosa Henry). Chestnuts and oaks were sampled near Fougères, France $\left(48^{\circ} 21^{\prime} 05.62^{\prime \prime} \mathrm{N}, 01^{\circ} 12^{\prime}\right.$ $\left.16.65^{\prime \prime} \mathrm{W}\right)$, while poplars and walnuts were sampled near Alès, France ( $44^{\circ} 07^{\prime} 37.934^{\prime \prime}$ N. $04^{\circ} 05^{\prime} 0.067^{\prime \prime} \mathrm{E}$ ). The sampled chestnuts and oaks were planted as grasslands' hedges, whereas walnuts and poplars were planted within grasslands plots (intraplot).

The selected trees were sampled in February 2019 to limit the seasonal impact on wood chemical composition (i.e., starch in sapwood). A total of 9 trees were sampled from which 15 branches were taken (one to three branches per tree). The details are summarized in Fig. 1.

For each species, the harvested branches were split in three sectors according to their distance to the tree trunk. The three branch sectors were defined as follows:

- Sector 1: $100 \%$ of the branch diameter at the knot's level;

- Sector 2: $70-90 \% \pm 3 \%$ of the branch diameter at the knot's level;

- Sector $3: 40-70 \% \pm 5 \%$ of the branch diameter at the knot's level.

A total of 45 branch sectors were sampled. The age of the branch wood is reported in Tab. 1, according to the tree species and the branch sector. Based on these data, we supposed than the majority of wood samples is mainly composed by sapwood portion or sometimes by transition wood, as for example in sector 1 for chestnut.

\section{Sample partitioning, conditioning and} density measurement

Each of the 45 branch sectors was firstly cut into diametric vertical planks $(30 \mathrm{~mm}$ width) using a band saw (Fig. 1), taking care of including both normal and tension wood (wherever present). The planks were then cut into wood sticks $\left(15 \times 5 \mathrm{~mm}^{2}\right)$ at four radial locations. The wood sticks were then cut into test pieces sized $25 \times 15 \times 5$ $\mathrm{mm}^{3}$ (L: longitudinal; T: tangential; R: radial). These samples were stabilized at a moisture content (MC) of $12 \%$ in humid air at $20{ }^{\circ} \mathrm{C} \pm 2{ }^{\circ} \mathrm{C}$ and $65 \% \pm 5 \% \mathrm{RH}$. Air-dried density of samples was determined by weighing and measuring their volume using a vernier caliper, prior to further testing. Overall, 1080 samples were prepared and used as shown in Fig. 1.

In addition, increment cores $(5 \mathrm{~mm}$ in di- 
ameter, $20 \mathrm{~cm}$ long) were taken from the trunk of sampled trees near the insertion zone of branches ( 1 core per branch, totaling 15 cores samples). Each core was cut in three parts $(5 \mathrm{~mm}$ in diameter, $25 \mathrm{~mm}$ long) that were used for extraction (using a protocol similar to that describe below), in order to compare the extractive content of the stem wood to that of the wood from the corresponding branches.

\section{Extraction processes}

All experimental procedures used in the determination of the extractive content were adapted, with minor modifications, from Rowell et al. (2005).

Each sample was dried at $103{ }^{\circ} \mathrm{C}$ to determine its initial anhydrous mass $\left(\mathrm{m}_{2}\right)$ and then extracted in a soxhlet with Toluene : Ethanol (Sigma Aldrich, 32201-M) 2:1 (v:v) solution $(2 \times 6 \mathrm{~h}$, intercalated by $15 \mathrm{~h}$ of maceration in the extraction solvents) following by distilled water $(2 \times 6 \mathrm{~h}$, intercalated by $15 \mathrm{~h}$ of maceration in the extraction solvents), and then dried at $103{ }^{\circ} \mathrm{C}$ for $48 \mathrm{~h}$ to obtain the anhydrous mass $\left(\mathrm{m}_{3}\right)$. The wood extractive content $(E)$, in percentage of dry weight (DW), was determined according to the following equation (eqn. 1):

$$
E(\% D W)=\frac{\left(m_{2}-m_{3}\right)}{m_{2}} \cdot 100
$$

where $m_{2}$ is the theoretical anhydrous mass of the test piece before extractions and $m_{3}$ is its anhydrous mass after the extractions. A total of 540 samples were characterized for their extraction rate.

\section{Decay resistance tests}

To carry out the durability screening test, the two following decay fungi were used: Trametes versicolor (L.) Lloyd (TV) and Coniophora puteana (Schumach.) P. Karst. $(\mathrm{CP})$, respectively a white rot and a brown rot fungi. These two fungi has been selected because they are mandatory by the XP-CEN/TS-15083-1 (2006) standard in the determination of natural decay resistance of hardwood species.

Decay tests were performed according to the procedure described by Bravery (1978). Sterile culture media were prepared with $40 \pm 0.5 \mathrm{~g}$ of malt extract and $20 \pm 0.5 \mathrm{~g}$ of powdered agar dissolved in $1 \mathrm{~L}$ of distilled water. They were then molded in glass containers, closed by cotton plugs to enable air circulation. The jellified culture media were inoculated with a piece of $1 \mathrm{~cm}$ in diameter. Then, the containers were incubated for two weeks in climatic chambers $\left(22 \pm 2{ }^{\circ} \mathrm{C}\right.$ and $\left.70 \pm 5 \% \mathrm{RH}\right)$, until a full colonization of the medium by the mycelium was reached.

Weight and humidity of the conditioned wood block samples were measured to determine their theoretical anhydrous mass $\left(\mathrm{m}_{4}\right)$, and then sterilized in an autoclave at $121{ }^{\circ} \mathrm{C}$ by two successive steps of $20 \mathrm{~min}$, before decay resistance tests. Two hundred seventy test pieces were tested per fungus. The incubation of test pieces was carried out for 8 weeks in a climatic chamber $\left(22 \pm 2{ }^{\circ} \mathrm{C}\right.$ and $\left.70 \pm 5 \% \mathrm{RH}\right)$. Once the fungal exposure was completed, samples were carefully cleaned from the fungus. All samples were then oven dried at $103^{\circ} \mathrm{C}$ for $48 \mathrm{~h}$ and weighed $\left(m_{5}\right)$. Mass loss (ML, \%) due to the decay degradation of the sample was calculated as (eqn. 2):

$$
M L(\%)=\frac{m_{4}-m_{5}}{m_{4}} \cdot 100
$$

The wood durability classes were then attributed according to the XP-CEN/TS-150831 (2006) standard.

\section{Near infrared spectroscopy measurements}

Near infrared spectra were obtained in the radial tangential plane of all test pieces, after a stabilization step performed at $20^{\circ} \mathrm{C} \pm 2{ }^{\circ} \mathrm{C}$ and $65 \% \pm 5 \%$ RH. Chaix et al. (2015) showed that regression models yield accurate predictions when measurements are made on this plane. A Bruker Vector 22/ $\mathrm{N}^{\circledR}$ spectrophotometer (Bruker Co., Billerica, MS, USA) and the OPUS ${ }^{\oplus}$ software ver. 5.5 were used in diffuse reflectance mode with a sintered gold standard as reference. Data were measured for wavelengths between 9000 to $4000 \mathrm{~cm}^{-1}$ (1100 to 2500 $\mathrm{nm}$ ), in $8 \mathrm{~cm}^{-1}$ increments. The spectra were composed by 648 wavelengths of reflectance values. Sixteen scans were performed and averaged for each measurement in order to improve the signal-tonoise ratio.

\section{Statistical analysis}

Statistical analysis was performed using the software RStudio Desktop ${ }^{\circledR}$ ver. 1.2 (RStudio Inc., Boston, MS, USA). To understand the evolution of the characteristics measured within branches, Kruskall-Wallis tests have been applied on each potential explicative factor and response variable. For each test indicating an effect of a factor on a studied variable, Wilcoxon tests were used to investigate the nature of this effect and the significance of the differences between different groups.

NIRS spectra were first transformed (Naes et al. 2004) with a Standard Normal Variate (SNV) correction to reduce the effect of irregularities of surface and the intra spectrum variability (correction of the light dispersion). The second derivative was then computed using the algorithm of Savitzky Golay with a smoothing range of 21 data points and a third degree polynomial (Savitzky \& Golay 1964). The use of this derivative allowed to separate overlapping peaks and correct the baseline deviation of spectra. Mathematical corrections were applied using the software package "prospectr" ver. 0.1.3. NIRS models to predict the density, the extractive contents and the mass loss were developed with the Partial Least Squares (PLS) regression method using the software package "pls", ver. 2.7.1. No outlier was removed in the models. The data was divided into two sets: a calibration set $(2 / 3$ of the total number of samples) and a validation set $(1 / 3)$. The property values to predict were first sorted and the validation set was built by picking one sample on three. The k-fold cross validation method was used on the calibration set with 10 random segments. The quality of the models was given by computing the following parameters (Naes et al. 2004): the coefficient of determination of calibration $\left(R_{c}^{2}\right)$, the standard error of calibration (SEC), the root mean square error of cross validation (RMSECV), the coefficient of determination of calibration $\left(R^{2}\right)$, the root mean square error of prediction (RMSEP), the ratio of performance to deviation (RPD).

\section{Results and discussions}

\section{Prediction of the wood density and} extractive content by NIRS modelling

Fig. $2 \mathrm{~A}$ presents the comparison of the density values predicted by PLS regression with the measured ones. Ten components were selected for the model. The coefficient of determination value was $R^{2} c=0.91$ (SEC $=0.04 \mathrm{~g} \mathrm{~cm}^{-3}$, RMSECV $=0.05 \mathrm{~g} \mathrm{~cm}^{-3}$ ) for the calibration set. The predictive performance of the model on the validation set was $R_{P}^{2}=0.89$, with a RMSEP value of $0.05 \mathrm{~g} \mathrm{~cm}^{-3}$. The values of SEC, RMSECV and RMSEP were sufficiently close and showed that the model was robust. The value of the ratio of performance to deviation was $\mathrm{RPD}=3.0$, highlighting that this model was suitable for predictions (Williams \& Sobering 1993). These results were in agreement with previous published studies (Gindlet et al. 2001, Schimleck et al. 2003, Mora et al. 2008, Hein et al. 2009, Leblon et al. 2013). Schimleck et al. (2003) showed that it was possible to accurately calibrate NIR models for a wide range of species that represent different taxa, wood chemistry and physical properties. NIR absorbance spectra are related to the chemical composition of the tested wood sample (Leblon et al. 2013). The NIR spectroscopy technique is usable in assessing wood physical properties (including density) because these properties vary with the chemical properties within a tree, but also because the infrared light contains information of chemical components (light absorption) associated with physical characteristics (light scattered) like surface texture or porosity (Burns \& Ciurczak 2008, Schwanninger et al. 2011, Sandak et al. 2016).

Fig. $2 \mathrm{~B}$ shows the result of the PLS regression to predict the extractive contents. The model was built with 7 components, and the $R^{2} c$ value was $0.86(\mathrm{SEC}=0.95 \%$ and RMSECV $=1.05 \%$ ) for the calibration set. The coefficient of determination for the validation set was $R^{2}=0.85$, with a RMSEP value of $0.96 \%$. As with density, this model was found to be robust, and the value of the ratio RPD was 2.6. Investigations on wood chemical composition, specifically on 
(Aa)

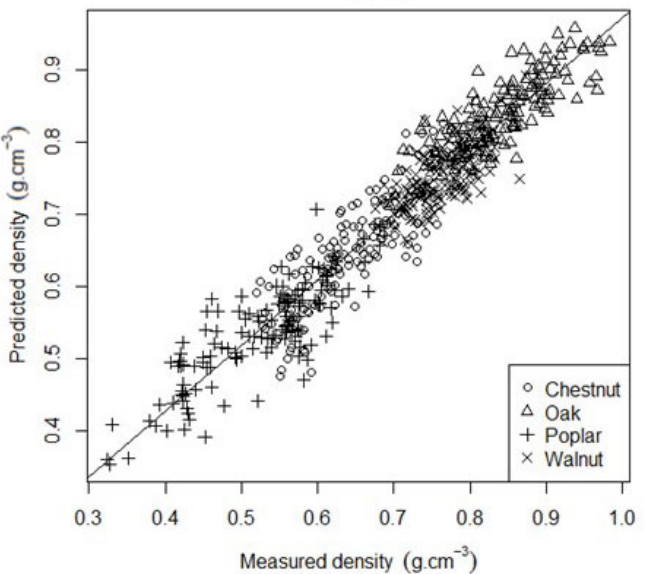

(Ba)

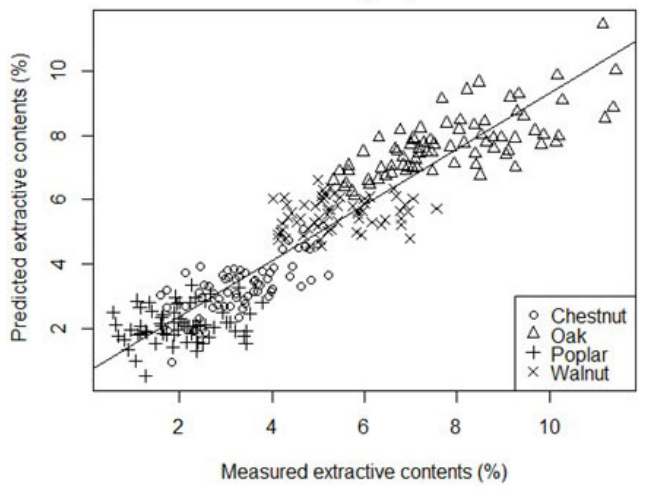

$(A b)$

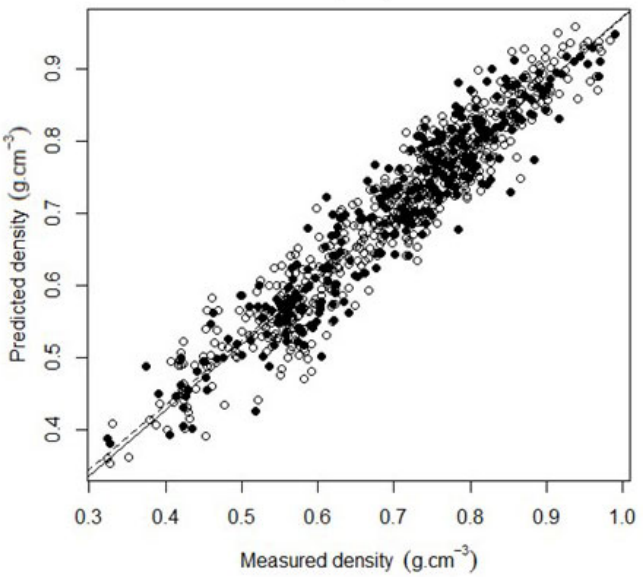

$(\mathrm{Bb})$

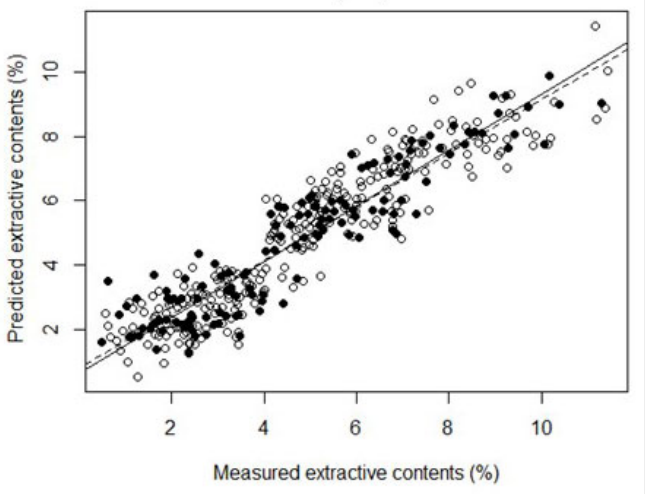

Fig. 2 - Relationship between measured and predicted density $(A)$ and branch wood extractive content (B) by NIRS modelling. (a) Calibration set with different marks by species; (b) calibration and validation set (white circle: calibration set; black circles: validation set). Continuous lines represent regression lines, while dotted lines are the identity lines $(y=x)$. extractive contents, using NIR were previously reported (Meder et al. 1999, Esteves \& Pereira 2008, Gierlinger et al. 2002, Tsuchikawa \& Kobori 2015, Razafimahatratra et al. 2018). Our results are in agreement with the findings of the aforementioned studies. Wood extractives include heterogeneous groups of chemical compounds, and they can be grouped by the type of solvent used during their extraction (Gierlinger et al. 2002, Razafimahatratra et al. 2018). Gierlinger et al. (2002) developed NIR models on wood powder and on solid wood to determine the hot water and acetone extractive content of Larix sp. The authors stated that the solid wood models were less predictive than those derived from wood powder because additional factors, such as the varying wood structure (e.g., earlywood vs. latewood within annual rings), sample geometry or surface properties, might add to the existing complex chemistry. The characteristics of the models related to solid wood were $R^{2}=0.74$ (RMSEP $\left.=1.88 \%\right)$ for the hot water extractives contents, and $\mathrm{R}^{2}{ }_{\mathrm{p}}=0.78$ (RMSEP $=0.36 \%$ ) for the acetone extractive content. A multi-species model was developed by Razafimahatratra et al. (2018) to determine the ethanol-toluene extractive contents with a portable spectrometer. The main characteristics were a coefficient of determination of cross validation of 0.64 and a RMSECV value of $1.54 \%$. The authors reported that the quality of the model was linked to the restricted spectral range and resolution of the portable spectrometer. The quality of the model might also have been the result of mixing of different chemical signature between species, adding to quantitative variations of composition within each chemical signature in each species.

\section{Predictability of the fungal durability by} NIRS modelling

Wood degradation is a topic of high interest in NIR wood research because it allows the detection of chemical changes as spectral variation (Tsuchikawa \& Kobori 2015). Fackler \& Schwanninger (2010) used NIR spectroscopy to investigate the overtones of $\mathrm{C}-\mathrm{H}$ and $\mathrm{O}-\mathrm{H}$ stretching vibrations; in particular, to better understand degradation processes of lignin, cellulose and hemicelluloses during brown rot. The mass losses induced by brown rots (Coniophora puteana, Gloeophyllum trabeum) and a white rot (Trametes versicolor) were predicted by NIRS measurements on Sequoia sempervirens (D. Don) Endl. samples (Jones et al. 2011). The spectra were acquired on the radial-longitudinal face of wood blocks. The authors found RPD ratios in cross-validation between 1.3 to 1.4 , and stated that the models could be used to separate the heartwood for high and low values of mass loss with fungal decay testing. Sykacek et al. (2006) investigated the natural durability of Larix spp. using the test fungi Gloeo- phyllum trabeum and Coniophora puteana. The authors obtained a coefficient of determination from cross validation of 0.93 and a RMSEP value of $3.3 \%$ for Coniophora puteana (with radial surface tests and a second derivative pre-processing)

In the present study, the regression coefficients between the data predicted by NIRS models and the observed data are very low when all the species are considered together ( 0.43 and 0.53 for TV and CP, respectively). The white rot induced mass loss is approached with a precision of $\pm 11 \%$ of the dry weight, and the brown rot induced mass loss with a precision of $\pm 7 \%$. Those precision levels are insufficient to reliably determine the durability classes of the wood. In that case, the NIRS models cannot be used to build reliable prediction models of the white and brown rot induced mass losses.

NIRS provides measures directly linked to the chemistry of the wood since it measures chemical bonds. As a consequence, it is expected that reliable models could be built to accurately assess the wood biochemical composition (i.e., extractive content) and its density, which is strongly correlated to this first variable. Although wood extractives and density are often correlated with wood durability, the NIRS models do not accurately predict the decay resistance of branch wood. The chemical composition of the extractive fraction of wood (chemical signature) largely depend 
on the woody species and this could explain the difficulty to build an accurate NIRS models to predict the fungal durability of wood.

\section{Variability of branches wood air-dried density}

\section{Variations between branches}

The wood density of branches appeared different both among and within species. Oak branches wood $\left(0.76 \pm 0.06 \mathrm{~g} \mathrm{~cm}^{-3}\right)$ resulted to be denser than walnut (0.68 \pm $0.04)$, chestnut and poplar wood ( $0.59 \pm$ 0.07 and $0.48 \pm 0.07 \mathrm{~g} \mathrm{~cm}^{-3}$, respectively). Regarding the oak samples, the wood densities of the branches Fo and F2 (0.78 \pm 0.04 and $0.80 \pm 0.06 \mathrm{~g} \mathrm{~cm}^{-3}$, respectively) significantly differed from those of the branches G1 and G2 (0.74 \pm 0.04 and $0.72 \pm$ $0.06 \mathrm{~g} \mathrm{~cm}^{-3}$, respectively) after the Wilcoxon tests, while there are no significant density variations between the branches of the oak $F$ or between those of the oak G. Like- wise, the chestnut branches of the trees $A$ and $\mathrm{C}$, and the poplar branches of the trees $\mathrm{J}$ and $\mathrm{K}$ all displayed significantly different densities. This intra-species density variation was not detected for walnut trees. For the studied species, the wood density was similar for all the branches within a single tree.

\section{Variations inside branches}

Within a branch, the wood density varied with the location of the wood. Fig. 3 shows that the variation of wood density with the distance from the trunk depends on the species. Unless for poplar, the wood that was closest to the trunk (sector 1: $0.67 \pm$ $0.13 \mathrm{~g} \mathrm{~cm}^{-3}$ on average) showed a significantly higher density than woods located further away from it (sectors 2 and 3: $0.61 \pm$ 0.12 and $0.61 \pm 0.11 \mathrm{~g} \mathrm{~cm}^{-3}$ on average, respectively). Concerning the radial location of the wood (Fig. 3), it appeared that the wood density of chestnut and poplar branches increases with the distance to the pith: the closest to the bark, the denser the wood is. The same tendency can be observed for oak, but neither for it nor for walnut wood does the distance to the pith significantly affect the density. It is rather clear that the variation in wood density along the radius is very different among species. For example some wood species like Dicorynia guianensis Amshoff show nearly no variations, while Parkia nitida Miq. has a density variation from 0.2 to 0.5 between pith and bark, within the trunk (Lehnebach et al. 2019).

Overall, branch wood density significantly decreases with the distance to the trunk and significantly increases with the distance to the pith. For all the considered species, the wood density is quite similar between trunks and branches but this point is to be confirmed with specific trials. Sarmiento et al. (2011) highlighted that trunk and branch xylem densities of various French Guiana tree species were significantly and positively correlated with ra-

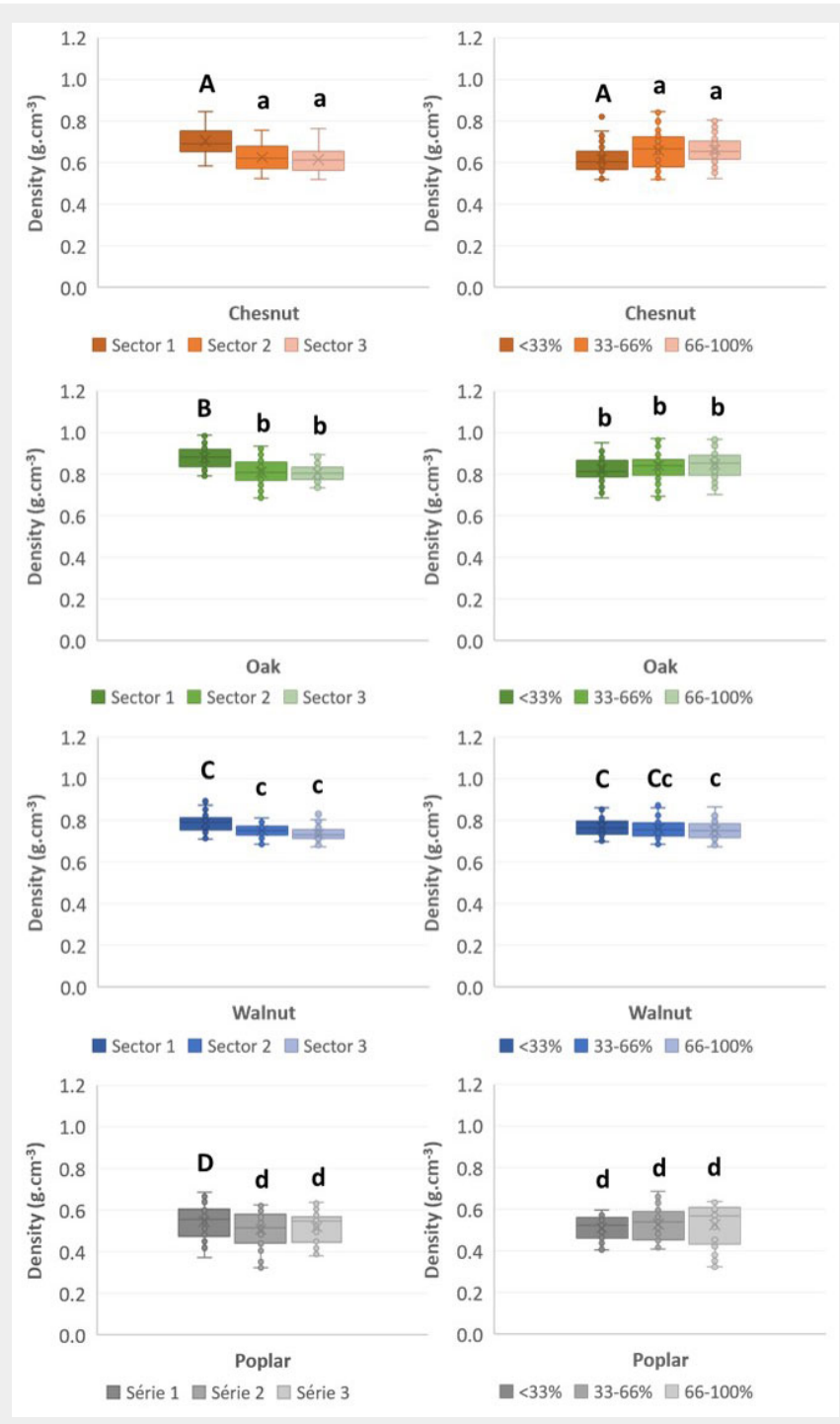

Fig. 3 - Mean density of branch wood in four hardwood species as a function of the distance to the trunk (left column) and to the pith (right column). Bars followed by the same letter are not significantly different.

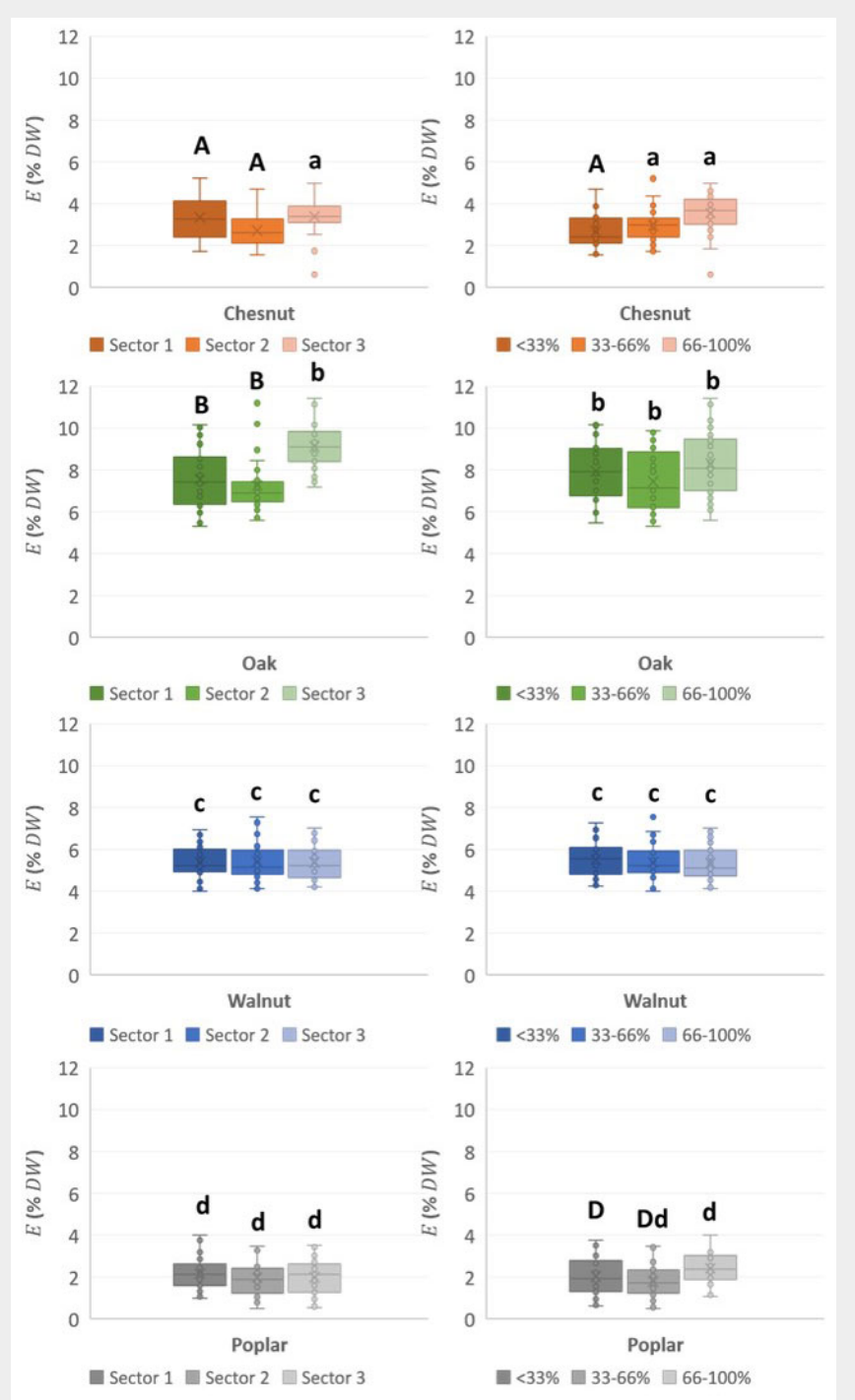

Fig. 4 - Mean extractive content of branch wood in four hardwood species as a function of the distance to the trunk (left column) and to the pith (right column). Bar followed by the same letter are not significantly different. 
Tab. 2 - Mean content of wood extractives (\% dry weight) in the knots and clear heartwood of the four hardwood species (from Kebbi-Benkeder 2015 and *Pietarinen et al. 2006a, 2006b).

\begin{tabular}{lrrrr}
\hline Component & Chestnut & Holm Oak & Walnut & Poplar* \\
\hline Knots (average of young, mild, old knots) & 17.4 & 14.2 & 10.9 & $<10$ \\
\hline Trunk heartwood & 10.3 & 12.7 & 13.3 & $<7$ \\
\hline Trunk sapwood & 7.3 & 9.3 & 6.3 & - \\
\hline
\end{tabular}

dial and longitudinal position within the branch or the trunk.

Branch wood density decreases when the distance to the trunk increases (Fig. 3). The fact that the sections of wood furthest from the trunk likely contain more juvenile wood than those closest to the trunk could explain this phenomenon. Gryc et al. (2011) and Latorraca et al. (2011) showed that the juvenile wood of 115 old-grown Norway spruce (Picea abies Karst.), 98 old-grown Scots pine (Pinus sylvestris L.) and 80 oldgrown European larch (Larix decidua Mill.) from the Czech Republic and 14 old-grown Black locust (Robinia pseudoacacia L.) trees from different forest sites in Eastern-Germany and Eastern Hungary, is produced during the first five year of life of the tree and it is less dense, less rich in extractives and less durable than mature wood which is produced later. However, such tendency is not so clear for all species and all growing conditions. There are very few evidence of typical variations in extractive content associated to juvenility, mainly because the deposition of extractives in the heartwood occurs much later than the thickening of the cell walls. On old trees with good durability, the resistance to rot is often much lower near the pith but this is mostly due to the age of the heartwood and its extractives near the pith. In addition, the wood density is related to the tree structure (Anten et al. 2010) and the trunk/branch junction has to be strong and resistant to degradation, with mechanical stresses very different from the trunk, due to the inclined growing of the branch.

The studied wood characteristics also present a radial pattern within branches that follows the same pattern as within trunks. McLean et al. (2011) noticed in trop-

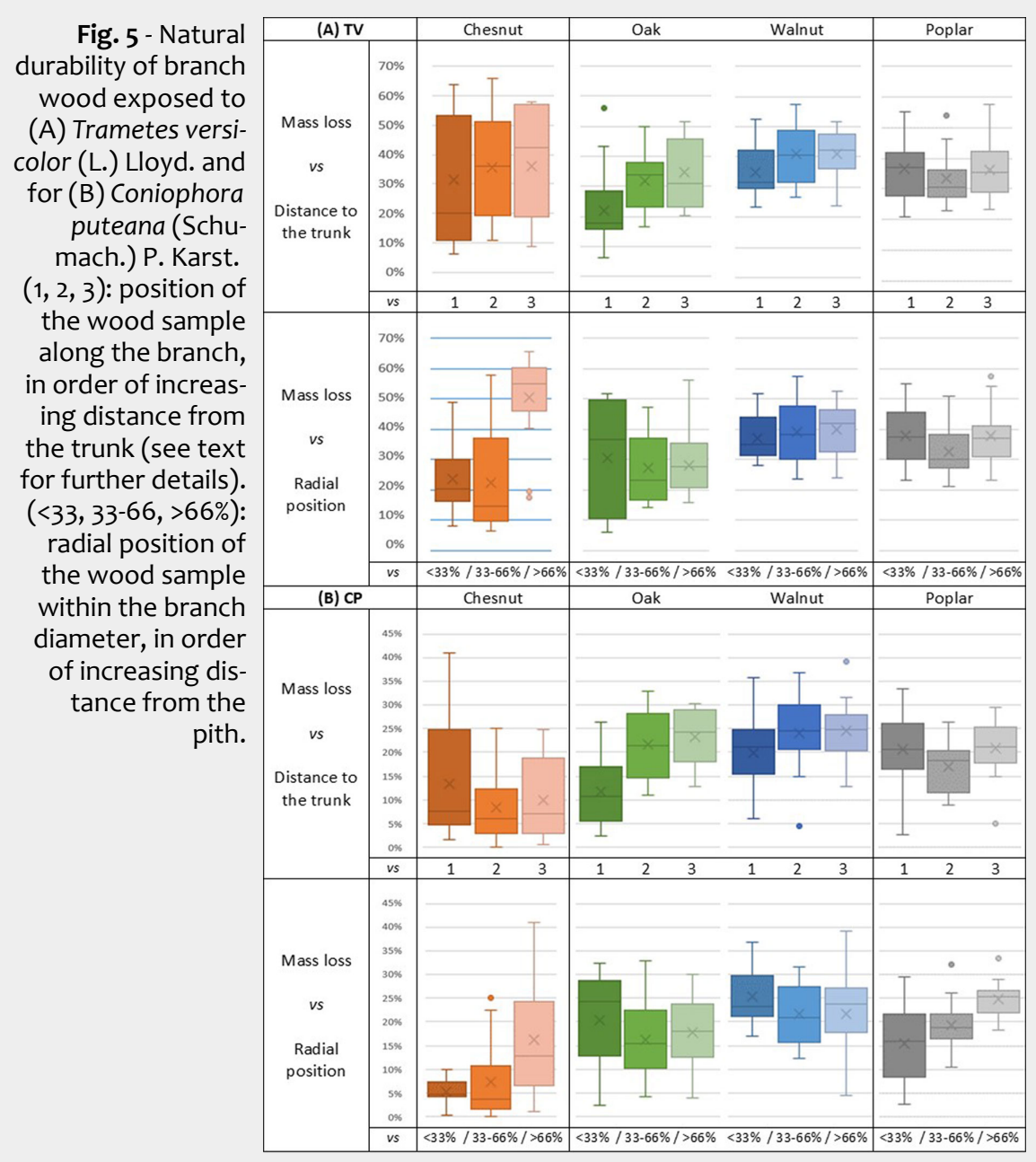

ical woods growing in dense forests that the wood density increases with its distance from the pith, but this is not true for the same species growing in open conditions like in plantations. Our result suggest that the same pattern is to be found on branch wood, as the average wood density next to the pith is significantly lower than that recorded at the distal end of the branch.

\section{Variability of extractive contents of branch woods}

\section{Variation among branches}

As shown in Fig. 4, the wood extractive contents were the highest in oak branches and slightly lower in walnut branches, while being still significantly higher in these than in poplar and chestnut branches. Within species, the extractive content of branch wood did not significantly differ, neither among the same trees nor among different trees. Considering all species, the extractive content seems to be lower in the branches than in the knots and even than in the trunk (Tab. 2), according to the findings of Kebbi-Benkeder (2015). This tendency has been confirmed in oaks and walnuts in this study. The extractive content has been evaluated on increment cores sampled in the trunk near the branch insertion zone and in the sapwood area (near the bark). On average, oak branches contained $7.9 \pm 1.5 \%$ of extractives and their corresponding samples from the nearby trunk contained $10.6 \%$. Walnut branches contained $5.4 \pm 0.9 \%$ of wood extractives while their trunk had $7.62 \%$. Chestnut and poplar branches were the poorest in wood extractives as they only contained $3.2 \pm$ $0.9 \%$ and $2.0 \pm 0.8 \%$ of those, respectively.

\section{Variation within branches}

Oak and chestnut extractive rates tended to increase with distance from the trunk (Fig. 4), but this tendency was only significant between the group of the two first sectors and the last one and did not appear in the case of walnut and poplar branches. In the radial direction, chestnut and poplar showed a slight but significant increase of extractive rates with the distance from the pith of the branches (Fig. 4). Such an evolution did not appear in the case of walnut and oak wood, which had the same extractive content level in the three radial positions. Globally, the variation of extractive contents linked to the distance from the pith is quite low and never exceed $+1 \%$.

Pooling the data of the four hardwoods species altogether, it appeared that the distance to the trunks did not significantly impact on the wood extractive contents. However, the radial locations of the wood in the branch did slightly differ in extraction contents, which increased when approaching the bark $(5.3 \pm 2.5 \%)$, perhaps showing a bark neighborhood effect, as the bark is usually rich of extractives. In addition, there are strong differences in ex- 
tractives in the sapwood, which can be due to nutrients like starch with high levels of variation depending on the season, and in the heartwood where extractives are mainly defense products with no significant variation among seasons.

\section{Variability of fungal decays of branch woods}

\section{White rot (Trametes versicolor - TV)}

Wood mass loss induced by white rot showed a large variation (Fig. 5A). Walnut wood showed the highest range of values (median value of $39.0 \%$ ), followed by poplar (median value of $35.4 \%$ ) and chestnut (median value of $34.4 \%$ ) then oak (median value of $28.2 \%$ ), which was in this case the most durable wood.

According to wood durability classes regarding white rot (Tab. 3), it seems that for all wood species, the durability of heartwood and sapwood from branches was particularly lower than that recorded for the trunk heartwood.

\section{Brown rot (Coniphora puteana - CP)}

A tendency similar to that observed with TV can also be detected with CP (Fig. 5B), mainly in oak (except for the wood near the pith) and chestnut wood; indeed, we found a decrease of durability when the ratio of sapwood grows (Fig. 5B). Pooling the data obtained for all the species, the distance to the trunk significantly affected the wood durability, which is in contrast with what observed when the radial position was considered (Fig. 6).

Wood durability tended to decrease from the trunk to the branch extremity and from the pith to the bark. This trend mainly concerned chestnut and walnut, and is likely due to the higher ratio of sapwood when moving from the trunk to the branch ends or from the pith to the bark. When the data obtained for all the four species were pooled, the distances to the trunk and to the pith had a significant effect on branch wood durability (Fig. 6).

Globally, the durability of the four hardwoods regarding brown rot fungi was higher than that towards white rot fungi, which is consistent with previous findings reported in the literature (Sun et al. 2017). Overall, the averages of mass loss were $17.6 \%$ and $34.2 \%$ for CP and TV, respectively. Walnut was always the less durable species, whilst oak the more durable to white rot and chestnut the more resistant to brown rot.

Our results showed that the coefficient of variation is higher for extractive contents than for density in almost every case. This was expected to some extent, as the variation of mass loss due to degradation is linked to both the chemical variation in the nature and the content of extractives and to the action of the fungi itself. Therefore, even for wood from the same tree with very similar chemical composition, rather large $C V$ values can be observed.

Tab. 3 - Mean values and standard deviations (SD) of mass loss due to fungal degradation and the associated wood durability classes (according to XP-CEN/TS-15083-1 2006) against Trametes versicolor (L.) Lloyd (TV) and Coniophora puteana (CP) and comparison with the durability class of trunk wood from similar woody species (*: CIRAD 2012a, 2012b, 2012c, 2012d).

\begin{tabular}{llcccc}
\hline \multirow{2}{*}{$\begin{array}{l}\text { Wood } \\
\text { origin }\end{array}$} & \multirow{2}{*}{\begin{tabular}{l} 
Parameter \\
\cline { 2 - 6 } Branches
\end{tabular}} & Chestnut & Oak & Walnut & Poplar \\
\cline { 2 - 6 } & Mean Mass loss due to TV (\%) & 34.4 & 28.2 & 39.0 & 35.4 \\
\cline { 2 - 6 } & SD Mass loss due to TV (\%) & 0.2 & 0.1 & 0.1 & 0.1 \\
\cline { 2 - 6 } & Durability class - TV & 5 & 4 & 5 & 5 \\
\cline { 2 - 6 } & Mean Mass loss due to CP (\%) & 10.4 & 17.7 & 22.60 & 19.5 \\
\cline { 2 - 6 } & SD Mass loss due to CP (\%) & 0.1 & 0.1 & 0.1 & 0.1 \\
\cline { 2 - 6 } & Durability class - CP & 3 & 4 & 4 & 4 \\
\cline { 2 - 6 } & Durability class & 5 & 4 & 5 & 5 \\
\hline Trunk & Durability class (CIRAD*) & 2 & 2 & 3 & 3 \\
\hline
\end{tabular}

The large dispersion of $M L$ values could be due to the wide range of diameters and ages of the branches sampled in this study. The durability screening tests ideally require the presence of several growth rings on a single sample and the test pieces were often too small to meet this requirement, which can lessen the precision of the results. Further, the measures were based on the dry weight of wood samples and, with a thickness of $5 \mathrm{~mm}$ only, it is possible that the sole manipulation of the test pieces altered their relative humidity, thus introducing a bias in the observed results.

\section{Conclusion}

This study provides new knowledge on branch wood from agroforestry systems, which are still under-studied so far. The results obtained highlight the evolution and variability of the physical and chemical characteristics of branch wood from agroforestry hardwoods. As reported by previous studies, wood density was quite similar in branches and in trunks. Indeed, the wood density along the branches decreased with the distance to the trunk and slightly increased with the distance to the pith. A similar pattern was observed for the extractive content of wood, but at a much lower level in branches than in trunks. According to the literature, also wood durability of the four hardwood species was much lower in branches than in trunks, but it seemed to decrease with the distance to the trunk and the pith. These last observations should be considered cautiously and additional experiments with bigger test pieces should be done to consolidate these conclusions. Ultimately, this study did not reveal any manifest suitability of branch wood from agroforestry practices for green chemistry, because of the quite low extractive ratios. However, further studies on the composition of wood extractive might throw light on the possible existence of molecule of interest in branch wood. Although woods from trunk and branches have a similar chemical signature for each given species, the content level of some

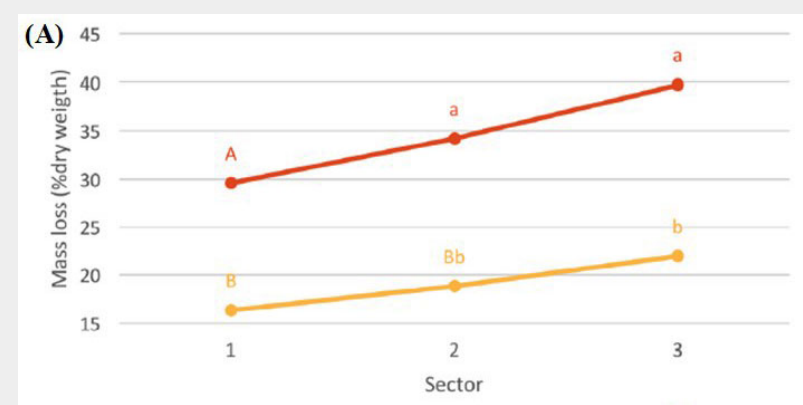

(B) 40

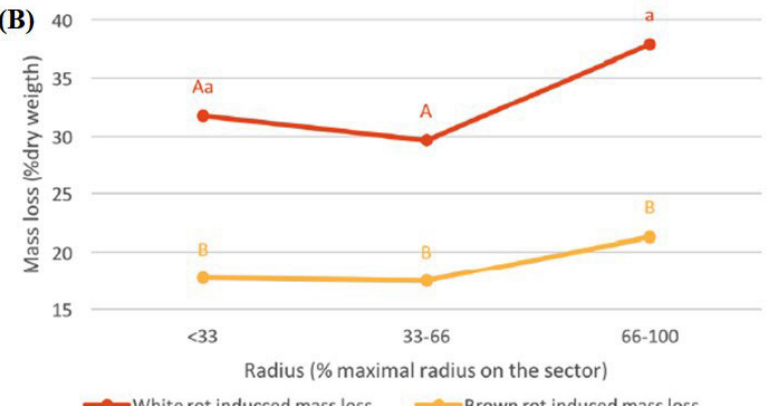

Fig. 6 - Median mass loss (\% of dry weight) of branch hardwood, depending on the infecting fungi and the distance to the trunk (A) and to the pith (B). Values followed by the same letter are not significantly different. 
chemical compounds may be higher in the branches than in the trunk. Furthermore, wood density in branches is equivalent to that of trunks, which suggest similar mechanical characteristics. This support the hypothesis that branch wood has an unused potential, in particular to manufacture biomaterials. Yet, the low extractive content and low durability levels of branch wood hamper its use in outdoor conditions. However, the wood of branches of these agroforestry species can be implemented as structural material in use classes 1 and 2, and 3 depending on the species, permeability and final use.

\section{Acknowledgements}

This work was financially supported by the French Environment and Energy Management Agency (ADEME) within the frame of the AGROBRANCHE (2018-2021) project ("Study of the valuation of branches in agroforestry for bio-based materials and green chemistry").

\section{References}

ADEME/Atlanbois (2016). Wood energy: current resources and prospects, keys to action? Environment and Energy Management Agency ADEME, Pays de la Loire, France, pp. 4. [in French]

Anten N, Schieving F, Dudley R, DeAngelis DL (2010). The role of wood mass density and mechanical constraints in the economy of tree architecture. The American Naturalist 175: 250260. - doi: 10.1086/649581

Bravery AF (1978). A miniaturized wood block for the rapid evaluation of wood preservative fungicides. Report no. 8-136: "II-Screening fungicides", Swedish Wood Preservation Institute, Stocholm, Sweden, pp 57-67.

Burns DA, Ciurczak EW (2008). Handbook of near-infrared analysis ( $3^{\text {rd }}$ edn). CRC Press, Boca Raton, FL, USA, pp. 834. [online] URL: http:// books.google.com/books?id=6EEdraoukaoC

Chaix G, Kokutse AD, Ratovomboahangy B, Guibal D, Randrianjafy $\mathrm{H}$, Rakotondraoelina $\mathrm{H}$, Brancheriau L, Rakotovololonalimanana $\mathrm{H}$, Hein PRG, Ramananantoandro T (2015). Prediction of radial and tangential shrinkages by near infrared spectroscopy: an example for Tectona grandis from Togo and for Liquidambar styraciflua from Madagascar. Cerne 16: 66-73. [online] URL: http://www.cerne.ufla.br/site/index.php/ CERNE/article/view/103

CIRAD (2012a). Fiche de l'essence chêne [File for oak species]. TROPIX 7 Les principales caractéristiques technologiques de 245 essences forestières tropicales, CIRAD, France, pp. 4. [in French] [online] URL: http://tropix.cirad.fr/Fi chiersComplementaires/FR/Temperees/CHENE. pdf

CIRAD (2012b). Fiche de l'essence châtaignier [File for Chestnut species]. TROPIX 7 Les principales caractéristiques technologiques de 245 essences forestières tropicales, CIRAD, France, pp. 4. [in French] [online] URL: http://tropix. cirad.fr/FichiersComplementaires/FR/Temperee s/CHATAIGNIER.pdf

CIRAD (2012C). Fiche de l'essence noyer [File for walnut species]. TROPIX 7 Les principales car- actéristiques technologiques de 245 essences forestières tropicales, CIRAD, France, CIRAD, France, pp. 4. [in French] [online] URL: http:// tropix.cirad.fr/FichiersComplementaires/FR/Te mperees/NOYER.pdf

CIRAD (2012d). Fiche de l'essence peuplier [File for poplar species]. TROPIX 7 Les principales caractéristiques technologiques de 245 essences forestières tropicales, CIRAD, France, pp. 4. [in French] [online] URL: http://tropix.cirad.fr/Fi chiersComplementaires/FR/Temperees/PEUPLI ER.pdf

Dadzie PK, Amoah M (2015). Density, some anatomical properties and natural durability of stem and branch wood of two tropical hardwood species for ground applications. European Journal of Wood and Wood Products 73: 759-773. - doi: 10.1007/s00107-015-0925-x

Dadzie PK, Amoah M, Frimpong-Mensah K, Shi SQ (2016). Comparison of density and selected microscopic characteristics of stem and branch wood of two commercial trees in Ghana. Wood Science and Technology 50: 91-104. - doi: 10.100 7/s00226-015-0763-3

Dupraz C, Liagre F (2008). Agroforesterie: des arbres et des cultures [Agroforestry: about trees and cultures] ( $1^{\text {st }}$ edn). Edition France Agricole, Paris, France, pp. 413. [in French] [online] URL: http://books.google.com/books?id= Xns4ZxvFtMIC

Esteves B, Pereira H (2008). Quality assessment of heat-treated wood by NIR spectroscopy. Holz Als Roh-und Werkstoff 66 (5): 323-3325. doi: 10.1007/s00107-008-0262-4

Fackler K, Schwanninger M (2010). Polysaccharide degradation and lignin modification during brown rot of spruce wood: a polarised Fourier transform near infrared study. Journal of Near Infrared Spectroscopy 18: 403-416. - doi: 10.1255 /jnirs.901

Gavaland A, Burnel L (2005). Growth and aboveground biomass of black walnut trees in an agroforestry plot at Les Eduts (Charente-Maritime). Chambres d'Agriculture 945: 20-22. [in French]

Gierlinger N, Schwanninger M, Hinterstoisser B, Wimmer R (2002). Rapid determination of heartwood extractives in Larix sp. by means of Fourier transform near infrared spectroscopy. Journal of Near Infrared Spectroscopy 10: 203214. - doi: $10.1255 /$ jnirs.336

Gindlet W, Teischinger A, Schwanninger M, Hinterstoisser B (2001). The relationship between near infrared spectra of radial wood surfaces and wood mechanical properties. Journal of Near Infrared Spectroscopy 9: 255-261. - doi: 10.1255/jnirs.311

Gryc V, Vavrčík H, Horn K (2011). Density of juvenile and mature wood of selected coniferous species. Journal of Forest Science 57: 123-130. doi: 10.17221/18/2010-JFS

Guitton JL (1994). L'agroforesterie? [Agroforestry? Agroforestry in temperate zones]. Revue Forestière Française 46: 11-16. [in French] - doi: 10.4267/2042/26605

Gurau L, Cionca M, Mansfield-Williams H, Sawyer $\mathrm{G}$, Zeleniuc O (2008). Comparison of the mechanical properties of branch and stem wood for three species. Wood and Fiber Science 40: 11. [online] URL: http://wfs.swst.org/index.php/ wfs/article/view/980
Hamon X, Dupraz C, Liagre F (2009). L'Agroforesterie, outil de séquestration du carbone en agriculture [Agroforestry: a tool for carbon sequestration in agriculture]. AGROOF, Bureau d'étude Spécialisé dans la Formation et le Développement des Pratiques Agroforestières, INRA, Anduze, France, pp. 17. [in French] [online] URL: http://www.agroforesterie.fr/docum ents/Agroforesterie-Outil-de-Sequestration-duCarbone-en-Agriculture.pdf

Hein PGR, Maioli Campos AC, Trugilho PF, Tarcísio Lima J, Chaix G (2009). Near infrared spectroscopy for estimating wood basic density in Eucalyptus urophylla and Eucalyptus grandis. Cerne 15 (2): 133-141. [online] URL: http://www. researchgate.net/publication/26638026

Jamnadass RH, Place F, Torquebiau EF, Malezieux E, liyama $M$, Sileshi GW, Kehlenbeck K, Masters E, McMullin S, Weber JC, Dawson IAK (2013). Agroforestry, food and nutritional security. ICRAF Working Paper no. 170, World Agroforestry Centre, Nairobi, Kenya, pp. 26. - doi: 10.5716/WP13054.PDF

Jones T, Meder R, Low C, O'Callahan D, Chittenden C, Ebdon N, Thumm A, Riddel M (2011). Natural durability of the heartwood of coast redwood (Sequoia sempervirens (D. Don) Endl.) and its prediction using near infrared spectroscopy. Journal of Near Infrared Spectroscopy 19: 381-389. - doi: 10.1255/jnirs.952

Kebbi-Benkeder Z (2015). Biodiversité interspécifique et intraspécifique des extractibles nodaux [Interspecific and intraspecific biodiversity of knots extractive compounds]. AgroParisTech Thesis, University of Lorraine, France, pp. 206. [in French] [online] URL: http://pastel.archivesouvertes.fr/tel-01374613

Kiaei M, Tajik M, Vaysi R (2014). Chemical and biometrical properties of plum wood and its application in pulp and paper production. Maderas Ciencia y Tecnología 16 (3): 313-322.

Košíková B (2009). Morphological and chemical characteristics of stem and knot poplar wood. Wood Research 54 (3): 117-122. [online] URL: http://www.woodresearch.sk/wr/200903/13.pdf Latorraca JV, Dünisch O, Koch G (2011). Chemical composition and natural durability of juvenile and mature heartwood of Robinia pseudoacacia L. Anais da Academia Brasileira de Ciências 83: 1059-1068. - doi: 10.1590/S0001-37652011005000 016

Leblon B, Adedipe O, Hans G, Haddadi A, Tsuchikawa S, Burger J, Stirling R, Pirouz Z, Groves K, Nader J, LaRocque A (2013). A review of near-infrared spectroscopy for monitoring moisture content and density of solid wood. The Forestry Chronicle 89 (5): 595-606. - doi: 10.5558/tfc2013-111

Lehnebach R, Bossu J, Va S, Morel H, Amusant N, Nicolini E, Beauchêne J (2019). Wood density variations of legume trees in French Guiana along the shade tolerance continuum: heartwood effects on radial patterns and gradients. Forests 10 (2): 80. - doi: 10.3390/f10020080 Malignier N, Balaguer F (2017). AGFORWARD annex to deliverable 1.2: current extent and trends of agroforestry in France. Association Française d'Agroforesterie, Auch, France, pp. 10.

McLean JP, Zhang T, Bardet S, Beauchêne J, Thibaut A, Clair B, Thibaut B (2011). The de- 
creasing radial wood stiffness pattern of some tropical trees growing in the primary forest is reversed and increases when they are grown in a plantation. Annals of Forest Science 68: 681688. - doi: 10.1007/s13595-011-0085-z

Meder R, Gallagher S, Macki KL, Böhler H, Meglen $R$ (1999). Rapid determination of the chemical composition and density of Pinus radiata by PLS modelling of transmission and diffuse reflectance FTIR spectra. Holzforschung 53 (3): 261-266. - doi: 10.1515/HF.1999.044

Michon G, De Foresta H (1992). Complex agroforestry systems and conservation of biological diversity: 2. For a larger use of traditional agroforestry trees as timber in Indonesia: a link between environmental conservation and economic development. In: "In Harmony with Nature. Proceedings of the International Conference on Conservation of Tropical Biodiversity" (Yap SK, Lee SW eds). Kuala Lampur (Malaysia), 12-16 June 1990. Malaysian Nature Society, Kuala Lumpur, MYS, pp. 488-500. [online] URL: http://www.documentation.ird.fr/hor/fdi:01005 4829

Mora CR, Schimleck L, Isik F (2008). Near infrared calibration models for the estimation of wood density in Pinus taeda using repeated sample measurements. Journal of Near Infrared Spectroscopy 16: 517-528. - doi: 10.1255/jnirs. 816

Morikawa T, Ashitani T, Kofujita H, Takahashi K (2014). Antitermitic activity of extracts from Chamaecyparis obtusa branch heartwood. European Journal of Wood and Wood Products 72: 651-657. - doi: 10.1007/s00107-014-0830-8

Mulia R, Dupraz C (2006). Unusual fine root distributions of two deciduous tree species in Southern France: what consequences for modelling of tree root dynamics? Plant and Soil 281: 71-85. - doi: 10.1007/s11104-005-3770-6

Naes T, Isaksson T, Fearn T, Davies T (2004). A user-friendly guide to multivariate calibration and classification. NIR Publications, Charlton, UK, pp. 344.

Nair PKR (1993). An introduction to agroforestry. Kluwer Academic Publishers, Dordrecht, Netherland, and International Centre for Research in Agroforestry, Boston, MA, USA, pp. 489. [online] URL: http://books.google.com/ books?id=CkVSeRpmlx8C

Nair PKR (1990). The prospects for agroforestry in the tropics. Technical Paper no. 131, World
Bank, Washington, DC, USA, pp. 77. [online] URL: http://www.cabdirect.org/cabdirect/abstr act/19910651635

Pecha B, Garcia-Perez M (2015). Chapter 26 - Pyrolysis of lignocellulosic biomass: oil, char, and gas. In: "Bioenergy, Biomass to Biofuels". Academic Press, Cambridge, USA, pp. 413-442.

Pietarinen SP, Suivi P, Willför SM, Vikström FA, Holmbom BR (2006a). Aspen knots, a rich source of flavonoids. Journal of Wood Chemistry and Technology 26 (3): 245-258. - doi: 10.1080/02773810601023487

Pietarinen SP, Willför SM, Ahotupa MO, Hemming JE, Holmbom BR (2006b). Knotwood and bark extracts: strong antioxidants fromwaste materials. Journal of Wood Science 52 (5): 436444. - doi: 10.1007/s10086-005-0780-1

Razafimahatratra AR, Rakotovololonalimanana $H$, Thévenon MF, Belloncle C, Chaix G, Ramananantoandro T (2018). Natural durability, ethanol-toluene extractives and phenol content prediction of eight wood species from Madagascar using NIRS multispecific models. In: Proceedings of the "Annual Meeting of the International Research Group on Wood Protection (IRG49)". Johannesburg (South Africa) 29 Apr3 May 2018. IRG, Stockholm, Sweden, pp. 6. [online] URL: http://agritrop.cirad.fr/588906/

Rowell RM, Pettersens R, Han JS, Rowell JS, Tshabalala MA (2005). Cell wall chemistry. In: "Handbook of Wood Chemistry and Wood Composites". CRC Press, Boca Raton, FL, USA, pp. 35-72. [online] URL: http://books.google. com/books?id=ekrLBQAAQBAJ

Sanchez PA (1995). Science in agroforestry. Agroforestry Systems 30: 5-55. - doi: 10.1007/BF 00708912

Sandak J, Sandak A, Meder R (2016). Assessing trees, wood and derived products with near infrared spectroscopy: hints and tips. Journal of Near Infrared Spectroscopy 24: 485-505. - doi: 10.1255/jnirs.1255

Sarmiento C, Patiño S, Paine CET, Beauchêne J, Thibaut A, Baraloto C (2011). Within-individual variation of trunk and branch xylem density in tropical trees. American Journal of Botany 98 (1): 140-149. - doi: 10.3732/ajb.1000034

Savitzky A, Golay MJE (1964). Smoothing and differentiation of data by simplified least squares procedures. Analytical Chemistry 36: 1627-1639. - doi: 10.1021/ac60214a047

Schimleck L, Evans R, Ilic J (2003). Application of near infrared spectroscopy to the extracted wood of a diverse range of species. IAWA Journal 24 (4): 429-438. - doi: 10.1163/22941932-9000 0347

Schwanninger M, Rodrigues JC, Fackler K (2011). A review of band assignments in near infrared spectra of wood and wood components. Journal of Near Infrared Spectroscopy 19 (5): 287308. - doi: 10.1255/jnirs.955

Sun G, Ibach RE, Faillace M, Gnatowski M, Glaeser JA, Haight J (2017). Laboratory and exterior decay of wood-plastic composite boards: voids analysis and computed tomography. Wood Material Science and Engineering 12: 263-278. - doi: 10.1080/17480272.2016.1164755

Sykacek E, Gierlinger N, Wimmer R, Schwanninger $M$ (2006). Prediction of natural durability of commercial available European and Siberian larch by near-infrared spectroscopy. Holzforschung 60: 643-64. - doi: 10.1515/HF.2006.108 Tsuchikawa S, Kobori H (2015). A review of recent application of near infrared spectroscopy to wood science and technology. Journal of Wood Science 61: 213-220. - doi: 10.1007/s10086015-1467-x

Williams P, Sobering D (1993). Comparison of commercial near infrared transmittance and reflectance instruments for analysis of whole grains and seeds. Journal of Near Infrared Spectroscopy 1: 25-32. - doi: 10.1255/jnirs.3

XP-CEN/TS-15083-1 (2006). Durability of wood and wood-based products - Determination of the natural durability of solid wood against wood destroying fungi - Test methods - Part 1: Basidiomycetes. European Committee for Standardization (CEN), Brussels, Belgium, pp. 20.

Xu F, Zhong XC, Sun RC, Lu Q, Jones GL (2007). Chemical composition, fiber morphology, and pulping of P. bolleana Lauche. Wood and Fiber Science 38: 512-519.

Young A (1991). Agroforestry for soil conservation. In: "Science and Practice of Agroforestry”. CAB International, Wallingford, UK, pp. 318.

\section{Supplementary Material}

Fig. S1 - Concentric organization of the wood and wood valorization paths depending on its location on the tree.

Link: Terrasse_3693@supploo1.pdf 